\title{
A MEZŐGAZDASÁGI VADKÁR ALAKULÁSA, JELLEMZŐI ÉS AZ ELLENE VALÓ VÉDEKEZÉS BEMUTATÁSA APÁTFALVA ÉS MAGYARCSANÁD KÖRNYÉKÉN
}

\author{
Lendvai Edina - Hízó Ildikó - Deák Dalma Mónika
}

\begin{abstract}
Absztrakt: Tanulmányunk célja felhívni a figyelmet a vadásztársaságok egyre fontosabb szerepére. A vadkár egyre erőteljesebben jelen van a mezőgazdaságban. Fontos, hogy ez ellen a vadgazdák és a gazdálkodók/termelők együttesen lépjenek fel. Ehhez szükséges ismerni a pontos fajt, ami ellen védekezni kell és a védekezési módszereket, melyeket akár közös találkozók alkalmával megoszthatnak egymással a gazdálkodók. Esetünkben az említett települések helyzetét nehezíti, hogy pont a határ mellett találhatóak. Ez esetben nagyon hasznosak lehetnek a házi praktikák, amiket a gazdák egymástól tanulhatnak meg. Az alapja mindennek az összefogás és egymás segítése.
\end{abstract}

Abstract: Our target to draw the attention the role of the hunting companies. The wild damage is increasingly present in agriculture. It is important that hunters and farmers/producers act against this wild damage. To do this, it is necessary to know the exact species, which you have to against and the methods of protection that farmers can share with each other even during joint meetings. In our case, the situation of these settlements is complicated by the fact that they are located near the border. In this case, the home practices what the farmers can learn from each other can be very useful. The basis for all this is the collaboration.

Kulcsszavak: vad, mezőgazdaság, vadásztársaság, strukturált interjú

Keywords: game, agriculture, hunting company, structured interview

\section{Bevezetés}

A vadfajok károkozása napjainkban egyre nagyobb hangsúlyt kap, mind a mező- és erdőgazdálkodással foglalkozóknál, mind pedig a vadgazdálkodást végző szakembereknél. A vadon élö állatok táplálékfelvételük közben, és a fajtól függő bizonyos viselkedésük során, kárt okozhatnak a mezőgazdasági kultúrnövényekben. „A mezögazdaságban okozott kár fogalmi körébe tartozik általában a föld terményeiben okozott minden kár, függetlenül a földek müvelési ágától. A szántóföld, a rét, a gyümölcsös, a szőlő, a bármilyen kert terményeiben okozott kár egyaránt „mezőgazdaságban” okozott kár.”(Klátyik, 2003).

A vadkár már nem újkeletü probléma, hiszen - mondhatni - egyidős a fölművelő ember megjelenésével, s így már 10-12 ezer éve napirenden van. A régi időkben a vad által okozott károkért való felelősségvállalás gondolata senkiben sem merült fel, hiszen ugyanúgy könyvelték el az emberek, mint a többi természeti tényező által okozott kárt. A XVIII. században hozott rendelkezések hoztak változást e téren. Legelőször az 1729. évi dekrétum XXII. cikkében és Mária Terézia 1767-ben megjelent Urbáriumában lelhető fel a vadkár fogalma. Még nem köteleztek közvetlen kártérítésre senkit sem, hanem próbáltak köztes megoldást kitalálni. Ekkor, ennek a problémának a kiküszöbölésére hozták be a vadászati robotot, mely alkalmával védték a jobbágyok vetéseit és szőlőjét. Évenként három nap jobbágyi vadászatra kötelezték az embereket, amelyhez a lőfegyvert és a lőszert a földesúrnak kellett biztosítania (Zoltán, 2006). II. József Vadászati Rendszabálya, amely 1786- 
ban jelent meg, már valódi vadkártérítésről rendelkezett (Tagányi, 1896). Ezt követően az 1802. évi XXIV. törvényben foglaltak már konkrétan megfogalmazták, hogy „,a vad által okozott károkért a vadtenyésztő úr a haladéktalanul végrehajtandó becsü szerint teljes elégtételt tartozik szolgáltatni”. Vadkárról csak akkor eshetett szó, ha a vadtenyésztés megállapítottnak bizonyult. Nem tett különbséget a különböző vadfajok által okozott kárban és az adott telken garázdálkodó vadat bárki kedve szerint elejthette. Az így lelőtt vadat az elejtőnek az illetékes úrnak át kellett adnia, és ezután követelhette a kár megtérítését (Zoltán, 1973).

A jelenleg hatályos jogszabály 2017. március elsején lépett hatályba. Az 1996.évi LV. vadászati törvény a vad védelméről, a vadgazdálkodásról, valamint a vadászatról, 75.§-ában foglaltak szerint: „A vadászatra jogosult az e törvényben foglaltak alapján köteles a vad által okozott kárt (a továbbiakban: vadkár) a károsultnak megtéríteni. (2) Vadkárnak minősül a) a gímszarvas, a dámszarvas, az őz, a vaddisznó, valamint a muflon által a mezőgazdaságban és az erdőgazdálkodásban, továbbá b) az őz, a mezei nyúl és a fácán által a szőlőben, a gyümölcsösben, a szántóföldön, az erdősítésben, valamint a csemetekertben okozott kár tíz százalékot (a továbbiakban: természetes önfenntartási érték) meghaladó része. (3) Ha a vadászatra jogosult a jóváhagyott éves vadgazdálkodási tervben a gímszarvasra és a vaddisznóra elöírt elejtési tervszámokat nem teljesíti, akkor a következő vadászati évben a bekövetkezett vadkár teljes egészében a vadászatra jogosultat terheli." 24/2017.(V.17.) FM rendelet alapján: "mezőgazdaságban okozott vadkár a vad táplálkozása, taposása, túrása vagy törése következtében a szántóföldön, gyümölcsösben és a szőlőben a mezőgazdasági kultúra terméskiesését előidéző károsítás."

Ezen törvény módosítására került sor 2018-ban, mely 2019. január 11-től van hatályban. Ennek értelmében: „A vadkár megtérítésére az köteles, aki a kárt okozó vadfajjal vadgazdálkodási tevékenységet folytat és annak vadászatára jogosult, valamint akinek vadászterületén a károkozás bekövetkezett." (2018. évi CXXXVII. törvény)

A 2019. február 7-én rendezett Vadgazdálkodási Konferencián elhangzott, hogy a Szent István Egyetem Vadvilág Megőrzési Intézete és a Nemzeti Agrárkutatási és Innovációs Központ Erdészeti Tudományos Intézete vezetésével hamarosan egy útmutatót állítanak majd össze annak érdekében, hogy segítsék és tájékoztassák az érdekelteket. A tájékoztató kiadványok az egységes mezőgazdasági, illetve az erdei vadkárfelmérési útmutató (EMVU; EEVU) névre hallgatnak (www.nak.hu).

\subsection{A vadkárok csoportosítása}

Taposáskár: az állatok táplálkozása vagy mozgása során keletkezhet ez a fajta kár. Túráskár: jellegzetesen a vaddisznó okozza a tavaszi és kora nyári időszakban ( 1 . ábra). Kaparáskár: a túráskár egyik helyi, speciális fatája, amely lényegében ugyanaz, mint a túráskár, csak ezt a szarvasok és az őzek végzik. Rágáskár (2. ábra): a vadállatok táplálkozása során keletkezik. Legeléskár: egészen a kikeléstől tavaszig, vagy aratásig is fellelhető (Walterné, 1990; Klátyik, 2003). 


\section{1. ábra: Vaddisznó túrása a kukoricaföldben}

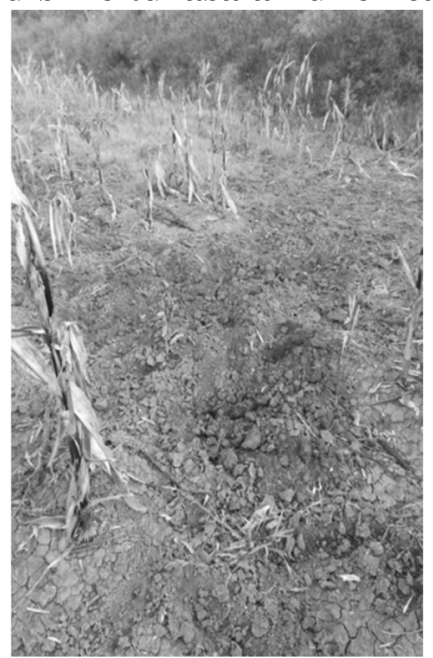

Forrás: Hízó I. saját felvétele

\section{2. ábra: Szarvas harapása a kukoricacsövön}

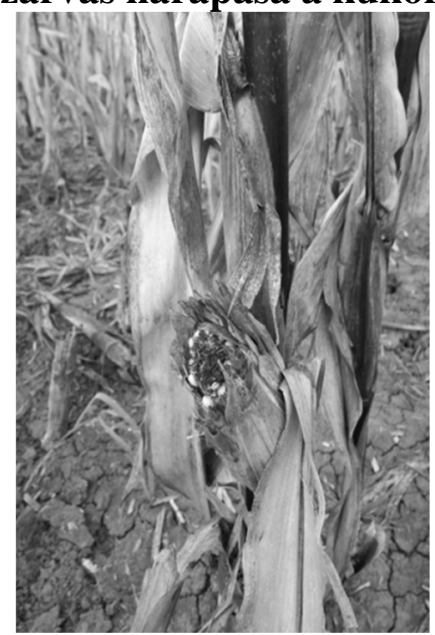

Forrás: Hízó I. saját felvétele

1.2. Néhány országban megvalósuló károk és megoldásuk - a teljesség igénye nélkül

A vadon élő állatok, a mezőgazdasággal foglalkozók és a vadgazdálkodást végző szakemberek közötti konfliktushelyzetről a világ minden tájáról érkeznek jelentések és az Európai Unióban is jelentős az aggodalom. Számos országban kapnak kártérítést a gazdálkodók és a szántóföldi növényekben okozott károk meghaladják a több millió eurót (Moore és mtsai, 1999).

Horvátországban a vadon élő állatok károkozásának és intenzitásának mértéke folyamatosan növekszik. Egyre magasabb gazdasági veszteségeket, hatást tapasztalnak az ott dolgozó szakemberek. A károk súlyosabbnak tünnek, mint Európa egyes részein. Legfőképpen a vaddisznó okoz problémát a mezőgazdasággal foglalkozóknak, de emellett a gazdák megemlítették még a szarvast, az özet, a barnamedvét, a borzot és a nyulat is. Az egyik leggyakoribb módja a károk 
csökkentésnek és a negatív pénzügyi veszteségnek egy biztosítás megkötése (KusakKrapinec, 2010).

Ausztriában a legföbb probléma a vaddisznó, amelynek állománya egyre növekszik, s így a kár mennyisége és a kifizetett összegek is egyre csak emelkednek (Reimoser-Reimoser, 2010).

Szlovéniában a kis szétszórt területek a leggyakoriabbak, amelyeknek egy része az erdők között, vagy erdősávok mellett található meg. Ezekben a parcellákban a leggyakoribb a kár, amelyet vaddisznó és szarvas szokott okozni. Az elmúlt 30 évben nőtt ezen állatok vadkár okozása, míg az őzé és más állaté pedig csökkent. A károkat a vadászatra jogosult köteles megtéríteni (Adamic-Jerina, 2010).

Lengyelországban is a vaddisznók okoznak gondokat a gabonafélékben. Megállapították, hogy a vaddisznó állományának növekedésével egyenes arányban növekszik a kár mértéke és a kifizetett vadkár nagysága. Ebben az országban nagyszámú európai bölény is van, amelynek a károkozását az állam fizeti ki (Wawrzyniak és mtsai, 2010).

\section{Anyag és módszertan}

Kutatásunk célja, hogy megismerjük a vadkár fogalmát, feltérképezzük a kialakulásának körülményeit, az ellene való védekezési módokat, illetve befolyásoló tényezőit.

A kutatási célterületként kiválasztott Maros Vadásztársaság Apátfalva és Magyarcsanád község bel- és külterületén végzi a vadgazdálkodási tevékenységét. Területük összesen $102 \mathrm{~km}^{2}$, amelyhez hozzátartozik még az ártéri rész is, hiszen a községek a Maros folyó mellett fekszenek. A folyó ezen a szakaszon államhatárként üzemel Románia és Magyarország között. Legfontosabb természeti értékei e területnek mindenekelőtt a Maros és ártere. A vízhez való közelség, az ártér változatos növényvilága és a megfelelő klímaviszonyok eredményezik, hogy gazdag és változatos élővilággal rendelkezik a terület. A 3. ábrán körbejelölve a vadásztársaság teljes vadászterülete látszódik. A vastagabb fehér vonal és a sötétszürkével csíkozott rész az ártéri területre utal 


\section{3. ábra: A Maros Vadásztársaság vadászterülete}

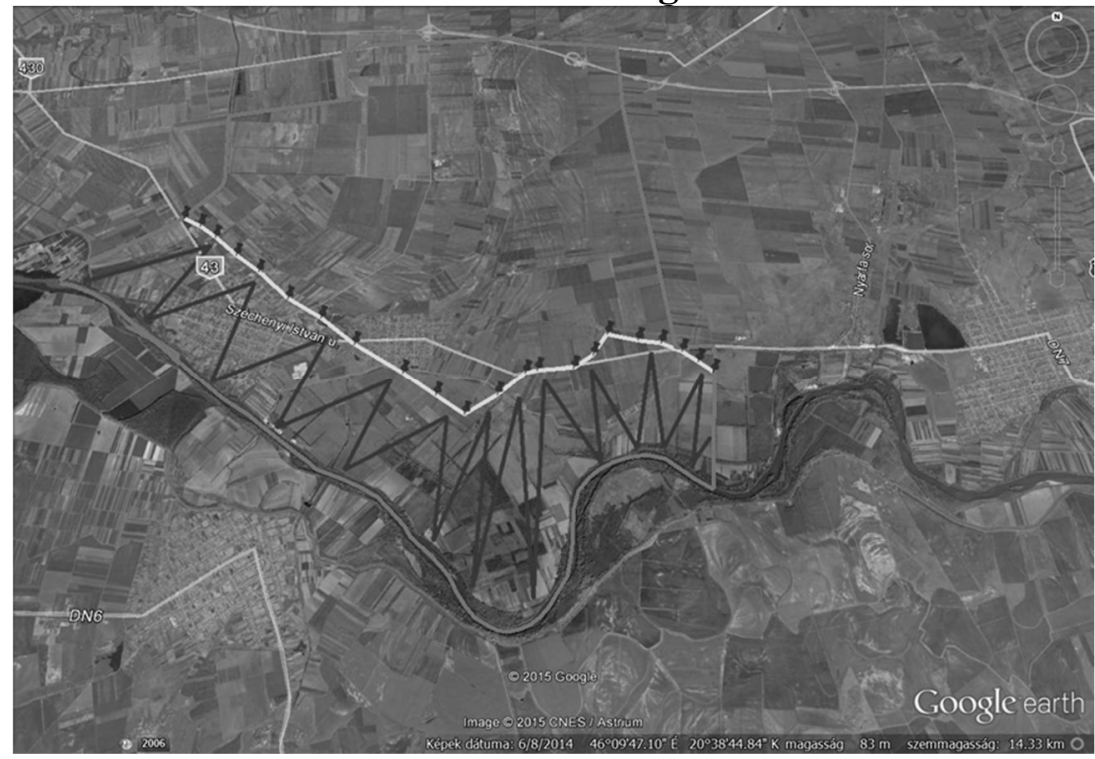

Forrás: Maros Vadásztársaság

Primer kutatásunk során strukturált interjút készítettünk nyolc, az adott területen mezőgazdasági tevékenységgel foglalkozó gazdával. Rajtuk kívül a Maros Vadásztársaság elnökével: Bálint Antallal, a Vadásztársaság vadászmesterével: Vári Csabával, illetve a Vadásztársaság egyik hivatásos vadászával: Langó Nándorral is elvégeztük a felmérésünket.

Jelen tanulmányunkban csupán a termelőkkel készített interjúkat mutatjuk be.

\section{Eredmények és értékelésük}

Elsőként kijelenthetjük, mind a nyolc termelő, minden évben szokott vadkárral szembesülni a szántóföldjén. Az okozott károkat az 1. táblázat szemlélteti

\section{1. táblázat: A leggyakoribb vadkár-fajták az egyes interjúalanyok esetében}

\begin{tabular}{|c|c|c|c|c|c|c|}
\hline & \multicolumn{3}{|c|}{ Kukorica } & \multicolumn{2}{|c|}{ Napraforgó } & \multirow[b]{2}{*}{ Búzavetés } \\
\hline Név & vetés & tejes érés & teljes érés & $\begin{array}{c}\text { pár leveles } \\
\text { állapotig }\end{array}$ & $\begin{array}{c}\text { virágzó } \\
\text { állapotban }\end{array}$ & \\
\hline Antal Dániel & $\mathbf{X}$ & & & & & $\mathbf{X}$ \\
\hline Antal Vince & $\mathbf{X}$ & $\mathbf{X}$ & $\mathbf{X}$ & $\mathbf{X}$ & & \\
\hline Bálint Dániel & & & & & & $\mathbf{X}$ \\
\hline Gyenge József & $\mathbf{X}$ & $\mathbf{X}$ & $\mathbf{X}$ & & & \\
\hline Langó Zsolt & $\mathbf{X}$ & $\mathbf{X}$ & $\mathbf{X}$ & & & \\
\hline Vancsó István & $\mathbf{X}$ & $\mathbf{X}$ & $\mathbf{X}$ & & & \\
\hline Varga Ferenc & & & & $\mathbf{X}$ & & \\
\hline Varga Zoltán & & & & $\mathbf{X}$ & $\mathbf{X}$ & \\
\hline
\end{tabular}

Forrás: A szerzők saját szerkesztése az interjúk alapján 
A kár nagyságát tekintve igencsak eltérő válaszokat kaptunk, 100.000 Ft-tól akár 400.000 Ft-ig terjedt a mértékük.

Hét gazda jelezte, hogy van lehetőségük a védekezésre, egy pedig azt állította, hogy nem áll módjában ezt tenni. A legtöbben úgy vélték, a villanypásztor a leghatásosabb módszer, bár eléggé költséges, igaz csak egyszeri komoly kiadást jelenthet. Abban is megegyezett a gazdák véleménye, hogy kisparcellás földek esetében nem éri meg villanypásztort telepíteni és fenntartani. A megkérdezett termelők nem mindegyikének van villanypásztora, de akinek nincs, az is elgondolkozott már a telepítésen. A visszatartó tényező sok gazdánál az, hogy a területen minden évben lopnak el villanypásztor berendezést és ettől félnek ők is. Emellett több gazda is védekezik más módszerrel, pl. van, aki káliszappannal óvja a napraforgóját a nyúl ellen. Más egy házi módszert alkalmaz, melynek lényege, hogy nagyon büdös öblítőbe áztatott ruhadarabot akaszt ki a szántóföld szélére. Van, aki fodrászokat kér meg, hogy a levágott hajat gyüjtsék össze, majd ezt a termőföld szélére rakja ki. Ezek a házi módszerek hatékonyságukat és költségüket nézve igen jónak bizonyulnak. A termelők úgy vélik, rajtuk kívül a vadásztársaság tud segíteni nekik. Elmondásuk szerint a vadásztársaság támogatja őket az őrzésben, a riasztásban. Azonban az ártéri részen a két kilométeres határzár miatt sajnos nem tudnak ilyen módon segítséget nyújtani. Ugyanakkor az egyik interjúalanyunk kiemelte: ha a gazda nem teszi meg a kellő intézkedéseket, akkor bármilyen más beavatkozás felesleges és nem várhatja mástól az eredményeket.

Ha bekövetkezik a kár, akkor a termelők a vadásztársasághoz fordulhatnak. Jellemzően csak a nagyobb károkkal keresik meg őket, olyanokkal, amelyeket már nem tudnak elviselni. Nem áll szándékukban pereskedni, bíróságra járni, tisztában vannak azzal, hogy a vadászok sem lehetnek kinn éjjel-nappal, hogy minden apróságot megakadályozzanak. A károsultak közül egy azt tanácsolja, hogy mielőtt a gazda bejelenti a vadkárt és elkezd vádaskodni, győződjön meg arról, hogy ő maga is mindent megtett az elhárítás érdekében. Más úgy gondolja, hogy a nagyvadállomány nagymértékü gyérítése hatásos módszer lenne, hogy kevesebb legyen a kár. Egy harmadik megkérdezett véleménye megegyezett ezzel, s hozzátette, hogy tudja jól, hogy az ártéri részben nem tudnak ezzel mit tenni a vadgazdálkodást végzők, így tehát az ,államnak kellene felfognia”, hogy mit is jelent ez a rendelkezés az e területen gazdálkodó termelőknek.

A gazdák közti összefogással kapcsolatosan a megkérdezettek azt mondták, igen hasznosnak érzik az ún. gazdaköri estéket. Egyrészt ilyenkor a gazdák megosztják a véleményüket és tapasztalataikat egymással, másrészt a szervezők különbözö témával kapcsolatban hívnak meg előadókat. Például az elmúlt időszakban egy villanypásztorokat forgalmazó cég képviselői tartottak előadást a védekezési módszerről, annak előnyeiről és hátrányairól. Négy gazda említette meg azt, hogy telefonos kapcsolatban vannak, ha valakinek valamilyen gondja van, vagy valaki valamit lát, akkor szól a másiknak.

A két kilométeres határzárral kapcsolatosan mindannyian ugyanazt mondták el: rossz dolognak tartják, véleményük szerint megnehezíti, és egyes esetekben ellehetetleníti mind a vadgazdálkodást végzők, mind pedig a mezőgazdasággal 
foglalkozók munkáját. A vadászok nem tudják teljes körủen végezni a munkájukat, így sokkal jobban meggyülik a bajuk a termelőknek a vadkárral, így a vadászoknak is a kártérítéssel. Úgy érzik, egy ördögi körbe kerültek a vadgazdálkodást végzők. Az, akinek az ártérben van szántóföldje hozzátette, hogy ameddig nem volt a határzár addig nem volt ilyen nagymértékü kár a területén, hiszen nagyon sokat segített, hogy éjszakánként, illetve amikor szükség volt a vadászok kinn lehettek a területen őrizhették a földet és megelőzhették a vadkárt.

\section{Következtetések, javaslatok}

A fent leírtak alapján az alábbi javaslatokat tesszük:

A mezőgazdasággal foglalkozók kezdjenek el időben gondolkodni és felkészülni a védekezésre, hiszen ugyanannyira érdekük, hogy megvédjék a földjüket, mint bárki másnak.

Ne sajnálják a pénzt a védekezési módokra, amelyek megóvják a földjüket, hiszen a jövőben nagyobb összegü lesz a terméskiesésből fakadó hiány, mint a védekezés ára lett volna.

Ne csak a földhasználók, hanem az országban müködő agráriummal foglalkozó szakemberek is legyenek naprakészek a vadkár ellenei védekezéssel kapcsolatosan. Segítsék a gazdálkodók munkáját és országos szinten foglalkozzanak a problémával.

A gazdálkodók ne elutasítóan álljanak hozzá a vadgazdálkodást végzőkhöz, hanem fenntartások nélkül jelezzék a gondjukat és kérjék a segítségüket. Abban az esetben, ha a vadgazdálkodást végző tanácsot ad az illető számára, pl. hogy melyik módszert használja, vagy milyen növényt vessen el a földbe, akkor azt fogadja el.

Javasoljuk, hogy alakítsanak ki jó kapcsolatot a másikkal, hiszen akkor sokkal könnyebb az együttmüködés és a közös munka.

\section{Irodalomjegyzék}

Adamic M., Jerina K (2010) : Ungulate management in Europe in the XXIth century: Slovenia https://www.researchgate.net/publication/250308630_UNGULATE_MANAGEMENT_IN_E UROPE_IN_THE_XXI_CENTURY_SLOVENIA

Klátyik J.(2003): Nemzeti kincsünk a vad... Vadkárok, vadászati és vadban okozott károk. Inga-V GSZI Kiadó, Pécs.

Kusak J., Krapinec K. (2010): Ungulates and their management in Croatia. 527-539. In:Apollonio M., Andersen R., Putman R. (szerk.) European Ungulates and their management in the $21^{\text {st }}$ Century. Cambridge University press, 604.p. https://books.google.hu/books?hl=hu\&lr=\&id=ycg5PtQPugC\&oi=fnd\&pg=PR9\&dq=European+Ungulates+and+their+management+in+the+ 21 st+Century.\&ots=JtC8JzHRHL\&sig=BT3qusc0v4jwHsfb5qbQdTEogBs\&redir_esc $=y \# v=o n$ epage\&q=European $\% 20$ Ungulates $\% 20$ and $\% 20$ their $\% 20$ management $\% 20 \mathrm{in} \% 20$ the $\% 2021 \mathrm{st} \%$ 20Century.\&f=false

Moore N., Whiterow A., Kelly P., Garthwaite D., Bishop J., Langton S., Cheeseman C. (1999): Survey of badger Meles meles damage to agriculture in England and Wales. Journal of Applied Ecology, 36, 974-988. https://besjournals.onlinelibrary.wiley.com/doi/full/10.1046/j.13652664.1999.00454.x

Reimoser F., Reimoser S. (2010): Ungulates and their management in Austria. 338-356. In: Apollonio M., Andersen R., Putman R. (szerk.) European Ungulates and their management in the 21st Century. Cambridge University press, 604.p. https://books.google.hu/books?hl=hu\&lr=\&id=ycg5PtQPugC\&oi=fnd\&pg=PR9\&dq=European+Ungulates+and+their+management+in+the+ 
21 st+Century.\&ots=JtC8JzHRHL\&sig=BT3qusc0v4jwHsfb5qbQdTEogBs\&redir_esc=y\#v=on epage\&q=European $\% 20$ Ungulates\%20and $\% 20$ their $\% 20$ management $\% 20 \mathrm{in} \% 20$ the $\% 2021 \mathrm{st} \%$ 20Century.\&f=false

Tagányi K.(1896): Magyar erdészeti oklevéltár. I-III., Budapest

Walterné I. V. (1990): A vadkár. Venatus kiadó, Budapest.

Wawrzyniak P., Jedrzejewski W., Jedrzejewska B., Borowik T. (2010): Ungulates and their management in Poland. 223-242. In: Apollonio M., Andersen R., Putman R. (szerk.) European Ungulates and their management in the 21st Century. Cambridge University press, 604.p. https://books.google.hu/books?hl=hu\&lr=\&id=-

ycg5PtQPugC\&oi=fnd\&pg=PR9\&dq=European+Ungulates+and+their+management+in+the+ 21 st+Century.\&ots=JtC8JzHRHL\&sig=BT3qusc0v4jwHsfb5qbQdTEogBs\&redir_esc $=y \# v=o n$ epage\&q=European $\% 20$ Ungulates $\% 20$ and $\% 20$ their $\% 20$ management $\% 20 \mathrm{in} \% 20$ the $\% 2021 \mathrm{st} \%$ 20Century.\&f=false

Zoltán J. (2006): Vadászat az Osztrák-Magyar Monarchiában. Dénes Natur Mủhely Kiadó.

Zoltán Ö. (1973): Felelösség a vadkárokért és a vadászattal kapcsolatos egyéb károkért. Közgazdasági és Jogi Könyvkiadó. Budapest

24/2017.(V.17.) FM rendelet: a vad védelméről, a vadgazdálkodásról, valamint a vadászatról szóló 1996. évi LV. törvény végrehajtásának szabályairól szóló 79/2004. (V. 4.) FVM rendelet módosításáról

https://net.jogtar.hu/jogszabaly?docid=A1700024.FM\&timeshift=fffffff\&txtreferer=0000000 1.TXT

2018. évi CXXXVII. törvény egyes törvényeknek az agrárgazdaság versenyképességével összefüggő módosításáról

https://net.jogtar.hu/jogszabaly?docid=A1800137.TV\&timeshift=fffffff4\&txtreferer=00000001 .TXT

https://www.nak.hu/agazati-hirek/mezogazdasag/148-erdo-es-vadgazdalkodas/98730-vadkarmediatorok-segithetik-az-egyeztetest 